\title{
Organization of the Learning Process and Motivation of the Students by their Teachers' in Educational Institutes
}

\author{
Nazyktere Hasani ${ }^{1}$ \\ Fatmir Agaj2 \\ ${ }^{1} \mathrm{PhD}$ candidate at European University of Tirana \\ Email:nhasani14@hotmail.com \\ ${ }^{2} \mathrm{PhD}$ candidate at European, University of Tirana \\ Email: fatmiragaj@hotmail.com
}

Doi:10.5901/jesr.2014.v4n2p281

\begin{abstract}
Motivation of the students by teachers during the learning process is an important aspect of mutual interest to students and teachers. The teacher as a relevant factor in the learning process, with his presentation and dedication, makes students become motivated for cooperation and involvement throughout the learning process, making clear, stimulate and encourage them in terms of analysis and critical thinking and profit sense of confidence. The research aimed to study and to reflect the attitudes of students and some of their opinions toward the organization of the learning process and toward the ability of teachers of motivating them to be active and interested throughout the learning process, and to compare estimates of the attitudes of high school students in two different municipalities. Research question of the study was: How do students estimate the organization of the learning process and teachers' engagement towards raising their motivation to participate actively in the learning process? Do we have differences in students' attitudes? Among the techniques that were applied in this study was the survey, which was conducted through a questionnaire for students. Analysis of the data from this survey indicates a low level of awareness of the teachers' for their motivational and supportive role they can have during the learning process. The data obtained from this study will probably lead us to increase the awareness of teachers to make efforts to encourage students to independent work skills, develop critical thinking and sense of self-confidence by creating cooperation, respect, and stimulation , and as the primary to estimate truly based on understanding of the ability of students to analysis that leads to their motivation to participate for the entire teaching process in the future for a better quality of effective learning.
\end{abstract}

Keywords: students' attitudes, teachers, high schools, motivation, learning process.

\section{Entry}

Student motivation for learning is a very important aspect which occupies a special place in the educational work of teachers. Increasing student motivation depends mainly on ways of bringing innovation by the teacher during the learning process, with a change of teaching, systematic and realistic assessment, stimulation of student abilities and skills, gaining confidence and mutual respect.

So as a key factor in raising student motivation is the teacher, where "His role and function today is a source of knowledge, transfer of knowledge, student coach, guide, spotter, instigator, consultant, assistance, heuristic." (Murat, 2005:5). We should see the need for possible changes, namely the teacher is the one who should be working to come up to change, creating enough space to students, so that students think critically, analyze and respect others opinion. Dedication to the students' attention, the personality respect and the creation of persuasion to judge us and credibility are some parameters that engage the interest of students to work actively throughout the learning process."Self trusting is the basis of creation of the mood and receiving students' attitude in learning. The aim of this strategy is to support the students build confidence and trust in themselves for to effectively work in teaching "(Musai, 1999:743).

Based on daily school life especially in motivating students and increasing interest to learn, a greater commitment from teachers is required, to take concrete steps in finding the best possible ways to encourage and motivate students in order to increase interest in learning. 


\section{Methodological Organization of the Study}

\subsection{Aim of the study}

The purpose of this study was to study and reflect the attitudes of students and some of their opinions towards the organization of the learning process and the commitment of teachers to motivate students to be active and interested in learning during the whole learning process, and to compare evaluations of the students' attitudes to school in two different municipalities.

\subsection{Research questions of the survey}

Research questions of the survey were:

1. How do students evaluate the education process and teachers commitment towards raising their motivation to participate actively in learning?

2. Do we have differences in students' attitudes?

\subsection{Objectives of the study:}

1. To analyze, compare and point out the opinions and attitudes of students toward engaging teachers towards their motivation for learning.

2. To provide recommendations to raise the awareness and readiness of teachers for possible changes, for flexibility by creating enough space for students to analyze, think critically and raise interest in finding different ways of communication.

3. Critical review of the literature

Numerous researchers in their general thoughts see the teachers as a relevant factor which with his work and his actions helps in increasing the motivation of students to participate actively in the learning process, so to be a subject in it. Teachers are those who:

With a good governance, mutual cooperation, guidance and encouragement of students, the teacher creates the proper conditions for them to act as a subject in school, in learning. "(Murati, 2004:440)

Also, the support and stimulation of students by teachers is an important prerequisite which affects in increasing the motivation and growth indicator of their interest in learning. According Jashari (2005:104),

Teacher should support students, to know precisely when to help and when to criticize or extol them in order to motivate them. When their progress is remarked then the teacher should allow carry them forward and to have privileges.

Shpend Rukiqi, says that "The teacher must be ready at any moment to show the student's journey. In other words to show up till where he has reached and how much he has to do "(Rukiqi, 2012:98). Musa (1999) in his book "Psychology of Education" describes "Knowing the result promotes learning." When the subject is known by the results it achieves, favours any kind of learning process.

So, recognition of the result, promotes positive energy to the students encourage that he from his side responds the feedback information to advance the learning process "(Musai, 1999:743). Thus, Kraja (2009) states that: "Motivation belongs not only to students but also to others. Students feel the weightiness of the note. (Kraja, 2009:330).

With a critical analysis of relevant literature, we see that the teacher is the relevant factor and influential in raising the motivation of students, who without a good management of the learning process and with stimulation, realistic assessment, support the creation of the trust would not create incentives and encourage student interest for that subject.

\section{Research Methodology}

This study was conducted in two secondary schools in different cities, Gjilan, Kamenica, where the attitudes have been reflected and students' opinions were taken of school students in research. In the survey a total of 320 students participated. Among the techniques applied was the survey, which was conducted through questionnaire.

The questionnaire contained 24 questions designed by the Liker level; I strongly disagree, I disagree, I agree and I strongly agree and closed questions. We asked some participants in the study to give some of their opinions on certain issues which they feel should be discussed.

1. Data, analysis and interpretation of the data obtained during the research. The table shows the total number 
of students.

\begin{tabular}{|c|c|c|c|c|c|c|c|c|c|}
\hline \multirow[t]{2}{*}{ No } & \multirow[t]{2}{*}{ Main Findings } & \multicolumn{2}{|l|}{$\begin{array}{l}\text { I totally } \\
\text { disagree }\end{array}$} & \multicolumn{2}{|c|}{ I disagree } & \multicolumn{2}{|l|}{ I agree } & \multicolumn{2}{|c|}{ I totally agree } \\
\hline & & St. & $\%$ & St & $\%$ & St. & $\%$ & St. & $\%$ \\
\hline 1 & $\begin{array}{l}\text { Teachers give us explanations } \\
\text { and collaborate in the learning } \\
\text { process }\end{array}$ & 84 & 26.2 & 117 & 36.6 & 78 & 24.4 & 41 & 12.8 \\
\hline 2 & $\begin{array}{l}\text { Teachers give us enough time to } \\
\text { think about the answer }\end{array}$ & 72 & 22.5 & 115 & 35.9 & 89 & 27.8 & 44 & 13.8 \\
\hline 3 & $\begin{array}{l}\text { Teachers give us the opportunity } \\
\text { to question, discuss, express } \\
\text { freely our opinions }\end{array}$ & 79 & 24.7 & 122 & 38.1 & 93 & 29.1 & 26 & 8.1 \\
\hline 4 & $\begin{array}{l}\text { Teachers pay attention to all } \\
\text { students and does not } \\
\text { discriminate }\end{array}$ & 67 & 21 & 121 & 37.8 & 68 & 21.2 & 64 & 20 \\
\hline 5 & $\begin{array}{l}\text { Teachers do not help enough } \\
\text { students who have learning } \\
\text { difficulties }\end{array}$ & 28 & 8.7 & 72 & 22.5 & 134 & 41.9 & 86 & 26.9 \\
\hline 6 & $\begin{array}{l}\text { Teachers during the evaluation } \\
\text { are affected by other teachers } \\
\text { grades and this makes us } \\
\text { disappointed }\end{array}$ & 38 & 11.9 & 99 & 30.9 & 118 & 36.9 & 65 & 20.3 \\
\hline 7 & $\begin{array}{l}\text { Teachers evaluate based on } \\
\text { sympathy, recognizing family and } \\
\text { going to their private courses }\end{array}$ & 53 & 16.6 & 74 & 23.1 & 117 & 36.6 & 76 & 23.7 \\
\hline 8 & $\begin{array}{l}\text { Teachers behave well, are realistic } \\
\text { during the evaluation and this } \\
\text { motivates us }\end{array}$ & 61 & 19.1 & 123 & 38.4 & 100 & 31.2 & 36 & 11.2 \\
\hline 9 & $\begin{array}{l}\text { Teachers make learning attractive } \\
\text { by bringing innovation to } \\
\text { encourage us more in learning }\end{array}$ & 82 & 25.6 & 122 & 38.1 & 86 & 26.9 & 30 & 9.4 \\
\hline
\end{tabular}

Table 1 Data summarized on students' perceptions toward their motivation by teachers The Legend: St-Student

From the analysis of data presented in the table above we note that in general students are not satisfied with the commitment of teachers in motivating them for an effective learning and have differences between responses to the findings given in the table. In this table are presented some data from survey questions, which will be interpreted and reflected graphically.

In the question 1: the teachers give us explanations and cooperate in during the lesson. Of the 320 participating students in the research 84 or 26.2 percent of them had said that they completely disagree, 117 or 36.6 percent of them responded that they do not agree what we note that 62.8 percent of them are not satisfied with the cooperation of teachers during the teaching process. Teachers as a leading player in the development of the learning process should create a positive working atmosphere in the classroom, cooperating with the students so it would increase the interest of students for learning and at the same time it would increase the students' success.

In the question 2: Teachers give us enough time to answer. About 58.4 percent of the students or 187 of them completely disagree and disagree with the opinion that teachers give them enough time to answer, while 133 or 41.6 percent think otherwise.

Graphic 1: Graphic presentation of the summarized data on student perceptions in \% over cooperation, explanations, possibility of the questions, discussion and expression of opinions

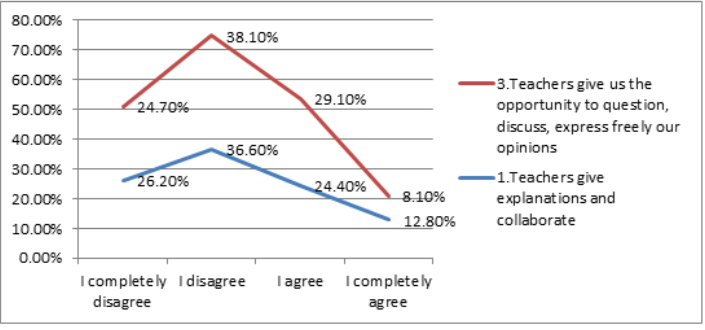


In the question 3: Teachers give us the opportunity to ask, discuss, and express our opinions freely. A considerable number of 201 students or 62.8 percent of them do not fully agree or disagree with this statement, while 119 of them or 41.2 percent completely agree or agree that teachers give the opportunity to engage in the learning process.

Giving the opportunity to question, discuss and express opinions by teachers increases the students' motivation to be active participants in the learning process and also they are given a positive energy to further interest in learning. The teacher is the one who creates a warm climate in the classroom by giving students the opportunity to ask, discuss freely so to students inspires a supportive and motivating thought.

In the question 4: Teachers pay attention to all students and do not discriminate. The majority of students participating in research 188 or 58.8 percent of them completely disagree and disagree, that teachers pay attention to all students and does not discriminate, while 132 of them or 41.2 percent deny such a thing. From this we see that there is a belief among students that teachers' attention to all students is lacking and that there are differences by them. Differences and not focused attention to all students affects their motivation to learn anything, they feel disappointment in their depth, and the breaking of their personality. So teachers need to devote attention to all students and not differ in order to make everyone feel equal.

In the question 5: Teachers do not help enough students who have difficulties in learning. Based on the results presented in the table, 100 students, or 31.5 percent of them completely disagree and disagree, while 220 students or 68.5 percent of them deny such a thing. Teachers as designers of the learning process should provide assistance to these students so that to them he inspires hope and a greater interest for an effective and qualitative learning. The following graph presents the percentage differences in the level of compliance.

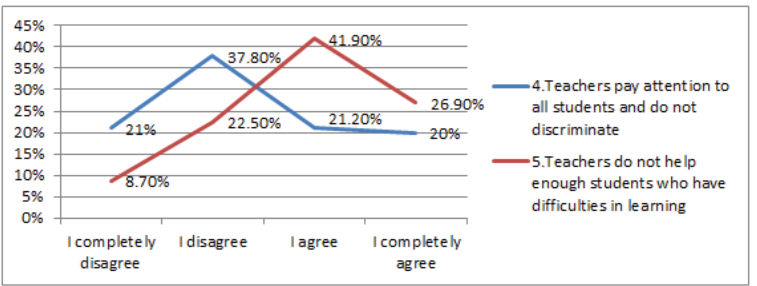

Graph 2: Graphic presentation of the data on students' perception in \% over the dedication of attention to students.

In the question 6:Teachers during the evaluation are affected by other teachers' grades which make us disappointed. 137 students or 42.8 per cent of them responded with strongly disagree and disagree, while 183 students or 57.2 percent of them said that they agree and fully agree that teachers evaluate based on other subjects grades. This shows that still lacks ethics of appreciating by teachers and that evaluation should not be based on the others evaluation, but based on the student's abilities he possesses.

In the question 7: Teachers evaluate based on sympathy, recognizing family and going to their private courses. Based on data derived we note that 127 students or 39.7 per cent of them were for alternative strongly disagree and disagree while 193 students or 60.3 per cent were expressed against. A high percentage indicates a thoughtlessness work of teachers. Teachers should be aware of the consequences that their wont brings to students, especially in the emotional life and development of their personality and disinterest in learning. The following graph shows the differences in the level of compatibility.

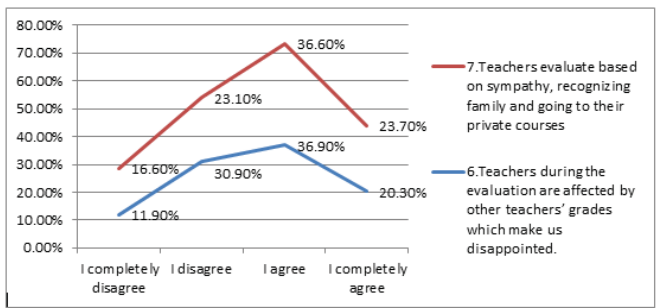

Graph 3: Graphic presentation in \% of the data on perception of the student over evaluation. 
Teachers behave well, are realistic during the evaluation and this motivates us.

From the data derived we note that, 184 students or 57.5 percent of them completely disagree or disagree, while 136 students or 42.4 percent of them agree and completely agree. These data highlight the teachers as bed evaluators, with not good behavior, not motivational to students, which creates a sense of dissatisfaction and interest for effective learning.

Teachers make learning attractive bringing innovation that encourages us to learn more. Of the total number of students participating in the research 204 or 63.7 per cent were of the opinion that teachers bring innovation in teaching which the conduct of innovation, the incentive of creativity, would encourage more their interest in being active part during the learning process.

\subsection{Students' opinions}

- I do not like the biology teacher, because she misbehaves with us, ask us difficult, requires a lot from us, during the evaluation she ask the lessons which we were previously estimated with, asks from us to say lessons the same as in the book, she is boring, she just explains and does not make the lesson interesting.

- We have teachers who do not help students who have "learning difficulties", they work only with the same students, do not give us the proper clarification, they criticize us.

- Very few teachers behave well with us, are willing to help us, try in every way to make the process learning interesting, understand us, does not discriminate students, call us in names, and this prompted us to love at every care courses and learning process.

- $\quad$ There are some teachers that give us notes every hour just to keep quietness in the classroom, and it makes the class monotonous.

- Teachers are not to blame, we students are not interested in learning, we make noise, do not listen to teachers, they do not have concretization equipments for science subjects, we do not have laboratories so that teachers are forced to explain, then the number of students in classes is very large and it is impossible to evolve the lesson.

\section{Conclusion and Recommendations}

Analysis of the data from this survey indicates a low level of awareness of the teachers for their motivational and supportive role that can play during the learning process. Based on the survey data we see that students do not appreciate the commitment of teachers to raise their motivation in participating actively in learning and in organization of the learning process. There is still the traditional way of teaching, but we should not always blame the teacher, but we should take into account the conditions in which he works and operates. Comparing the perceptions of students from both schools have noted that we do not have differences in their responses. Based on the perceptions of students, teachers are not sufficiently involved in the process of teaching; they are not cooperative and supportive, lack of teaching methodology because bringing innovation in learning and their actions increase to student the motivation and interest to be active during the learning process. So that all teachers should make maximum effort to satisfy the needs of students, to be more cooperative, to evaluate based on analytical skills, critical thinking and on skills of the students, to stimulate their work, so that the interest in learning will increase joining forces to a quality learning lesson. This study will probably lead us to increase the awareness of teachers for a greater commitment in terms of increasing student interest in learning, to make efforts to encourage independent work skills to students, develop the critical thinking and the sense of self-esteem by creating a spirit of cooperation, respect, and stimulation, principally to evaluate truly based on the understanding of the student's ability for analyzing and to create a mutual trust between the two pairs, which leads to their motivation in participating through the entire learning process in the future for a better quality and effective learning.

\section{References}

Cowley, S. (2006): Tajne uspješnog rada u razredu, vještine, tehnike i ideje. Zagreb:

Školska knjiga. [The secrecies of successful work in the classroom, skills, techniques and ideas ]

Glasser, W. (1999): Nastavnik u kvalitetnoj školi. Zagreb: Educa [ Teacher in Qualitative school]

Glasser, W. (2005), Kvalitetna skola-skola bez prisile. Zagreb, Educa [Qualitative school - unenforcemented]

Jashari,H.(2005), Sociologjia e arsimit. Shkup, 104 [ Sociology of education]

Juric, V. (1974), Ucenikovo pitanje u nastavi. Zagreb: Skolska knjiga [ Asking students in learning] 
Kamenarac,O(2009).Razvoj komunikacijskih kompetencija-potreba i nuznost. Beograd [ Developement of communication competencesneed and obligatory]

Kraja,M (2009) Pedagogjia.Tiranë,330 [ Pedagogy]

Murati,Xh(2004).Pedagogjia e përgjithshme. Shkup,440 [General pedagogy]

Murati,Xh(2005).Ndryshimi i arsimtarit dhe ndryshimet në shkollë. Tetovë,5 [Teachers' changes and changes in school]

Musai,B(1999).Psikologjia e edukimit. Tiranë,743 [ Psychology of education]

Rukiqi,Sh(2012) Mësimdhënie e balancuar. Prishtinë,98 [Balanced teaching]

Vidović V., Rijavec M., Vlahović-Štefić V., Miljković D. (2003). Psihologija učenja i poučavanja, Zagreb [Psychology of learning and teaching ]

Sources from the internet

https://www.google.com/\#q=motivacija+djaka+od+strane+nastavnika+za+ucenje [visited 12/23/ 2013 5:45]

http://web.math.pmf.unizg.hr/nastava/metodika/materijali/motivacija.pdf 6;06 [visited 12/23 /2013]

http://osstanojemiljkovic.nasaskola.rs/files/Inkluzija/Edukativni\%20materijal/Osnovni_principi_ucenja.pdf [visited 12/23/2013 6:10pm]

https://www.google.com/\#q=motivacija+djaka+od+strane+nastavnika+za+ucenje\&start=10 [visited 12/23/2013 6:15pm]

http://www.istrazime.com/skolska-psihologija/kako-motivirati-dijete-za-ucenje/[ visited 12/23/2013]

http://www.skolskenovine.hr/tjednik_arhiva.aspx [visited 1/5/2014 2:38pm] 